\title{
CRISIS MANAGEMENT PROCESS: A LITERATURE REVIEW AND A CONCEPTUAL INTEGRATION
}

\section{Veronika Vašíčková*}

\begin{abstract}
The 21st-century business environment requires permanent crisis management. Nowadays, managers seek to deal with a potential crisis effectively, with minimum losses or to avert the potential crisis in the best case. It can be noted that crisis managers must react proactively. Crisis management (CM) can be generally characterised as sets of approaches, measures and methods used in situations where managerial skills are no longer sufficient. The goal is obvious: minimise the impact of the crisis or avoid a potential crisis. The purpose of this paper is a literature review of crisis management approaches and, based on its summarisation, to propose a conceptual model respecting the proactive features and variables of the crisis management process. The paper highlights various definitions of $\mathrm{CM}$ approaches by various academic researchers and some empirical studies. A total of 98 literature sources have been reviewed for the research contribution. Particular attention is given to proactive models, which were described by many authors. All these models and approaches are analysed. The paper's findings discuss crisis management process features and proactive aspects in a proposed Proactive Crisis Management Process (PCMP) model.
\end{abstract}

Keywords: crisis management, crisis management process, crisis management approaches JEL Classification: M10, M19

\section{Introduction and Literature Review}

Crisis management has become a common content for the managers of organisations in view of the nature of the current business environment, which is influenced by the impact of globalisation and high market dynamics. In this world, a crisis can be considered more or less permanent (Rais, 2007). This fact requires control and a prediction that will avert the potential disruption of the organisation's balance and stability. In general, crisis management can be understood as a process that directs organization's activities for the purpose of capturing and evaluating the warning signals of a potential crisis (Mitroff and Pearson, 1993; Mitroff and Alpaslan, 2003; Paraskevas, 2006; Sahin and Ulubeyli and Kazaza, 2015). It could be stated that in the modern concept of crisis management it is almost necessary to strive for a proactive management style, where almost daily, the tasks of managers are to detect the warning signals that can avert a possible crisis and create measures to protect the organisation from a future crisis. A significant role is played by an analysis of the potential crisis and knowledge sharing leading to subsequent organisational learning (Robert and Lajtha, 2002; King, 2002; Wagner, 2005). The key role of managers, especially the crisis manager, is formed. Managers have to deal with many changes and ensure an efficient course of solving the problems. Previous studies and research in this field are looking for ways, procedures and methods to make crisis management

* University of Economics, Prague, Faculty of Management (veronika.vasickova@vse.cz). 
as effective as possible - in the sense of dealing with the crisis with the lowest possible losses (Paraskevas, 2006; Pollard and Hotho, 2006). It can be stated that an organisation's preparedness for a crisis is becoming a fundamental, although not strategic, management issue.

The purpose of this paper is a literature review, the summarisation of the knowledge acquired from it and finding common features of mentioned crisis management approaches and models. Part of this aim is to find directions for this particular field, which as such, will serve as the grounds for future research and theory. The literature survey will allow an interpretation of existing research from a new point of view and a combination with previous research (Knopf, 2006; Saunders, Lewis and Thornhill, 2012). The effective way to conduct this research is through the use of the internet and databases. Therefore, Google Scholar was used to search for research papers first. Initially, "crisis management" and "crisis management approaches" were used as the search keywords. First, the following papers were analysed: "Reframing crisis management" by C. M. Pearson, J. A. Clair (1998) and "From crisis prone to crisis prepared: A Framework for crisis management" by C. M. Pearson and I. I. Mitroff (1993). Second, after the analysis of these papers, other keywords such as "proactive crisis management", "reactive crisis management" and "crisis management process" were generated and refined. The following diagram shows the other keywords using a Boolean operator. It was necessary to exclude sources describing disaster management. Therefore, the keywords "crisis management" was searched with the specification "crisis management NOT disaster management". After the final determination of the keywords, the databases and citation indexes EBSCO, ProQuest Central, JSTOR and Web of Science were used.

\section{Figure 1 | Relevance tree for keywords search}

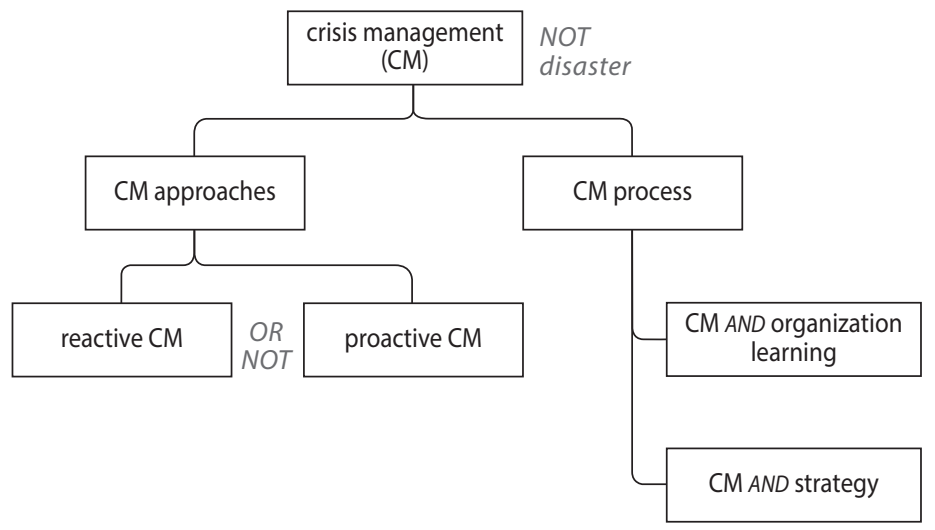

Source: Author's own processing

These literature sources were studied to understand the various research issues being explored by the researchers in crisis management approaches. Overall, 98 sources have been reviewed but, this set of 98 sources does not include all sources which were used in this review of crisis management approaches. More sources, found through the crossreferences, have been reviewed due to their influential role in the development of crisis management. The main reasons for excluding sources from the review are duplicates, irrelevant abstracts and topics with the field of studies, irrelevant content or the papers only included editorial notes. Some of these literature sources were about crisis 
management in the general content and some of these proposed possible approaches to solving the potential crisis. It was observed that many of these sources, although they provided literature reviews on crisis management approaches, also provided empirical studies on proactive crisis management. These studies were also included in this research. The total amount of eligible papers and other sources that underwent analysis and synthesis was 38. These steps are depicted in the following Figure 2.

Figure 2 | Flow diagram for reporting literature review study location, selection and evaluation

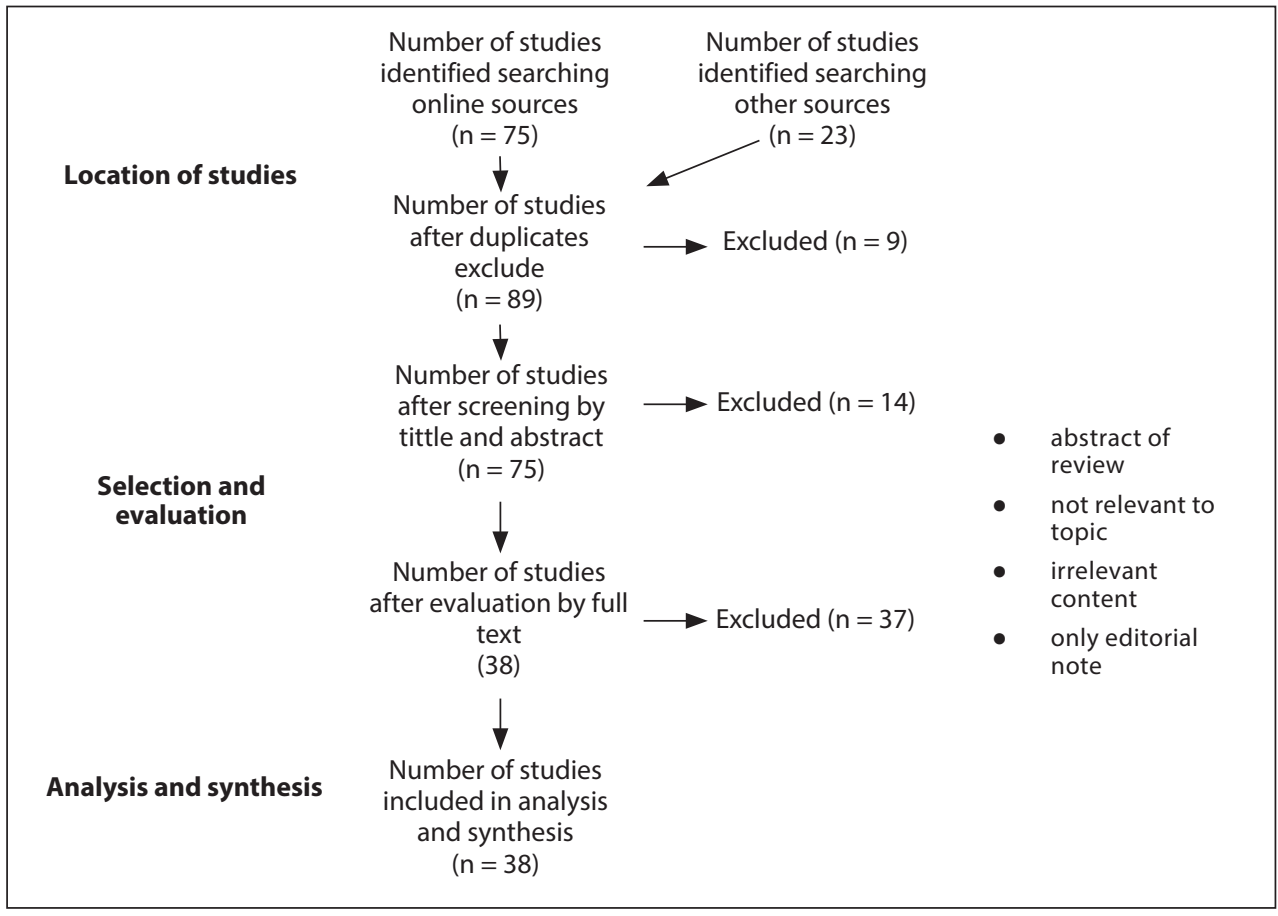

Source: Author's own processing

The literature review discusses two main domains of the crisis management field. First, the literature review focuses on crisis management as a process and describes the features as having a proactive character. Second, the main approaches of crisis management are described - the reactive and proactive approaches. The crisis management approaches are mainly examined and proposed for models with the element of a continual process highlighting the features of proactive crisis management style. Therefore, the models are finally analysed and discussed. Figure 3 shows the key authors that provide and discuss a crisis management process and framework with the two main approaches - reactive and proactive. The analyses and synthesis of this research are mentioned in the following Chapter 1.2. Approaches to Crisis Management: analysis and discussion. Figure 3 shows the main contribution of the author(s) research and the research type is also mentioned. In most cases, exploratory or conceptual research provides explanations of the author's ideas and premises. There are also four papers based on empirical research. 
Figure 3 | Summary of literature focus on crisis management approaches

\begin{tabular}{|c|c|c|}
\hline Author(s) & Contribution to research & Methodology \\
\hline Jaques, T. (2010) & $\begin{array}{l}\text { Issue and Crisis Management Relational model exploring } \\
\text { crisis management activities such as cluster or related } \\
\text { and integrated activities occurring simultaneously. CM } \\
\text { as a cyclical construct. }\end{array}$ & conceptual research \\
\hline Frybert, B. (1995) & $\begin{array}{l}\text { Algorithm for crisis solutions emphasizing the strategy } \\
\text { revitalization. }\end{array}$ & explanatory research \\
\hline $\begin{array}{l}\text { Mitroff, I. I.; } \\
\text { Pauchant, C. \& } \\
\text { Shrivastava, P. } \\
\text { (1988) }\end{array}$ & $\begin{array}{l}\text { System approach to crisis management from } \\
\text { using a process model which identify phases that } \\
\text { are necessary for an effective crisis management from } \\
\text { a process standpoint. }\end{array}$ & empirical research \\
\hline $\begin{array}{l}\text { Pearson, Ch. M.; } \\
\text { Clair, J. A. (1998) }\end{array}$ & $\begin{array}{l}\text { Descriptive model of crisis management process } \\
\text { and multidisciplinary approach to crisis management } \\
\text { research. }\end{array}$ & explorative research \\
\hline $\begin{array}{l}\text { Sahin, S.; Ulubeyli, S.; } \\
\text { Kazaza, A. (2015) }\end{array}$ & $\begin{array}{l}\text { Description of the activities of crisis management process } \\
\text { highlighting an importance of warning signals detection. } \\
\text { Authors define some approaches to crisis management } \\
\text { also. }\end{array}$ & exploratory research \\
\hline $\begin{array}{l}\text { Pearson, Ch. M.; } \\
\text { Mitroff, I. I. (1993) }\end{array}$ & $\begin{array}{l}\text { Crisis management framework a process leading } \\
\text { to organizations ' crisis preparedness. The stakeholders` } \\
\text { role are highlighted too. }\end{array}$ & $\begin{array}{l}\text { explorative, } \\
\text { conceptual research }\end{array}$ \\
\hline $\begin{array}{l}\text { Pollard, D.; Hotho, S. } \\
(2006)\end{array}$ & $\begin{array}{l}\text { Highlighting a strategic position of crisis management. Crisis } \\
\text { management with scenario planning process to provide } \\
\text { a mechanism for managing future crisis. }\end{array}$ & $\begin{array}{l}\text { exploratory, } \\
\text { conceptual research }\end{array}$ \\
\hline $\begin{array}{l}\text { Shrivastava, P.; } \\
\text { Mitroff, I. (1987) }\end{array}$ & $\begin{array}{l}\text { Description of corporate crisis and examines the strategies } \\
\text { for dealing with them. The role of crisis management team. }\end{array}$ & $\begin{array}{l}\text { exploratory, empirical } \\
\text { research }\end{array}$ \\
\hline $\begin{array}{l}\text { Shrivastava, I.; } \\
\text { Mitroff, I. I.; Miller, R. M.; } \\
\text { Miglani, S. (1998) }\end{array}$ & $\begin{array}{l}\text { Conceptual framework for understanding industrial crises. } \\
\text { Organizations must minimize their destructive potential } \\
\text { therefore the impact on stakeholders is evident. }\end{array}$ & $\begin{array}{l}\text { exploratory, empirical } \\
\text { research }\end{array}$ \\
\hline Spilan, J. E. (2000) & $\begin{array}{l}\text { The necessity of developing the strategies for proper } \\
\text { decision making before, during and after crisis occurs. Two } \\
\text { models of crisis management process. }\end{array}$ & $\begin{array}{l}\text { empirical, } \\
\text { exploratory research }\end{array}$ \\
\hline Valackiene, A. (2011) & $\begin{array}{l}\text { Conceptualization of crisis management model } \\
\text { concentrating on individual`s social identification } \\
\text { and perspective of communication. }\end{array}$ & conceptual research \\
\hline
\end{tabular}

Source: Author’s own processing

\subsection{Crisis Management as a Process}

Many definitions of crisis management have been modified for several years by authors dealing with this issue. Based on the literature, we can characterise many features describing this field of study. Crisis management (Mitroff and Pearson, 1993; Mitroff and Alpaslan, 2003; Antušák, 2009; Zapletalová, 2012; Mikušová, 2013; Sahin and Ulubeyli and Kazaza, 2015) should be understood as the process with related steps and procedures, which lead to early prediction of a potential crisis, identification (detection) of the nature of the crisis situation and successful resolution on time, and last but not least, facilitation of crisis averting. Crisis management is not always possible to avert the crisis, but organisations can manage it much more efficiently with minimal loss (Mitroff, Pauchant and Shrivastava, 1988; 
Sahin, Ulubeyli and Kazaza, 2015). All crisis management activities should be considered as a permanent continuous process beginning with prevention by the company and ending with organisational learning (Mitroff, Pauchant and Shrivastava, 1988; Shrivastava, 1988; Antušák, 2009; Zuzák and Konigová 2009). With this, we can see the necessity of a permanent process with using the feedback for other solutions and preventive action. A crisis management mechanism requires the incorporation of the employees' and stakeholders' interest (Shrivastava and Mitroff, 1987; Shrivastava, Mitroff and Miglani, 1988; Pearson and Clair, 1998; Valackiene, 2011; Sahin, Ulubeyli and Kazaza, 2015; Mikusova and Horvathova, 2019). According to Khodarahmi (2009), it is necessary to have clearly defined crises goals, which are subsequently modified from the strategic goals. This fact must be properly justified, in particular, to preserve their trust and loyalty. Therefore, one of the key activities of crisis management is the clear definition of goals and objectives, especially in the phase of dealing with the crisis.

Crisis management intentions and procedures include the creation of preventive programmes or mechanisms that prevent a potential crisis, deal effectively with losses and damage, and restore business performance (Shrivastava, Mitroff, Miller and Miglani, 1988; Valackiene, 2011). An important role of crisis management is played by a crisis team that can effectively and flexibly respond to the situation (Shrivastava and Mitroff 1987; Pearson and Clair, 1998; King, 2002; Zuzak and König, 2009; Antusak, 2009; Sahin, Ulubeyli and Kazaza, 2015; Mikušová and Horvathova, 2019). Crisis management procedures and mechanisms should be integrated into the overall organisation strategy, which should be revitalised after every new crisis situation (Shrivastava and Mitroff 1987; Preble, 1997; Spillan, 2000; Antušák, 2013; Crandall, Parnell and Spillan, 2013; Mikusova and Horvathova, 2019). Crisis management can be seen as a significant, often critical, part of strategic management within which potential threats should be identified (Gundel, 2005; Khodarahmi, 2009). In crisis management and strategy, we can see several common features, which include consistent analysis of the environment, cooperation with stakeholders and the top management activities. Common efforts lead to the creation of crisis scenarios and plans that can be considered both as a crisis management procedure and as a central part of the strategic planning process (Schoemaker, 1993).

\subsection{Crisis Management Approaches: Description and Analysis}

Crisis management can be characterised in several approaches or models. These approaches have been commented on and developed by many authors (Bertnard and Lajtha, 2002; Pollard and Hotho, 2006, Paraskevas, 2006; Antusak, 2009; Sahin, Ulubeyli and Kazaza, 2015; Mikusova and Horvathova, 2019; Mitroff, Pauchant and Shrivastava, 1988; Shrivastava, 1994; Frýbert, 1995; Pearson and Clair, 1998; Mitroff and Pearson, 1993; Spillan, 2000; Wagner, 2005; Zuzak and Königova, 2009; Valackeine, 2011; Sahin et al., 2015). Several approaches and models are mentioned and described in this paper, but in general, this discipline can be divided into two main approaches: a reactive and proactive approach.

The reactive approach to crisis management is generally understood as a set of procedures and principles (Loosemore and Hughes, 1998; Zuzak and Königova, 2009; Zapletalova, 2012; Sahin, Ulubeyli and Kazaza, 2015) to help bring the affected business out of the crisis and stabilise it. This approach has a clear procedure and begins with the identification of the crisis. A simple algorithm begins with awareness of the crisis and its identification. This phase is followed by crisis management, which has the clear 
objective of stopping the crisis. The resulting crisis is analysed in detail and the causes of the crisis are identified. Based on these analyses, the procedure leading to corrective actions is determined. An essential part of this process is organisational learning, or learning from the crisis, which provides the company with important information for further crisis measures and management (Shrivastava, 1988; Mitroff and Pearson, 1993; Zuzak and Königova, 2009).

In the first literature references to this issue (Fink, 1986; Shrivastava and Mitroff, 1987; Mitroff, Pauchant and Shrivastava 1988; Mitroff and Pearson, 1993; Shrivastava, 1994; Augustine, 1995; Frýbert, 1995; Preble, 1997; Pearson and Clair, 1998; Boin and Lagadec, 2000), a proactive way is viewed by discussing the necessity of anticipating and analysing a crisis during an organisation's stability. A proactive style is already explained in contemporary literature and research that the identification of a potential crisis begins before it hits the organisation. All activities are aimed at a systematic analysis of the warning signals that enable early detection of a potential crisis and the creation of system for early identification of potential (Mitroff, Pauchant and Shrivastava, 1988; Mitroff and Pearson, 1993; Kouzmin, 2008; Zuzak and Konig, 2009; Jaques, 2010; Sahin, Ulubeyli and Kazaza, 2015; Mikusova and Horvathova, 2019). Analysis papers include various models describing the main approaches mentioned. In the following paragraphs, these models are described, analysed along with the critically evaluated authors' contribution to this field of study.

The first of these models was interpreted by Sahin et al. (2015), where crisis management can be characterised by five approaches: escaping approach, solution approach, proactive approach, reactive approach and interactive approach.

\section{Figure 4 | Crisis management approaches by Sahin et al.}

Crisis Management Approaches

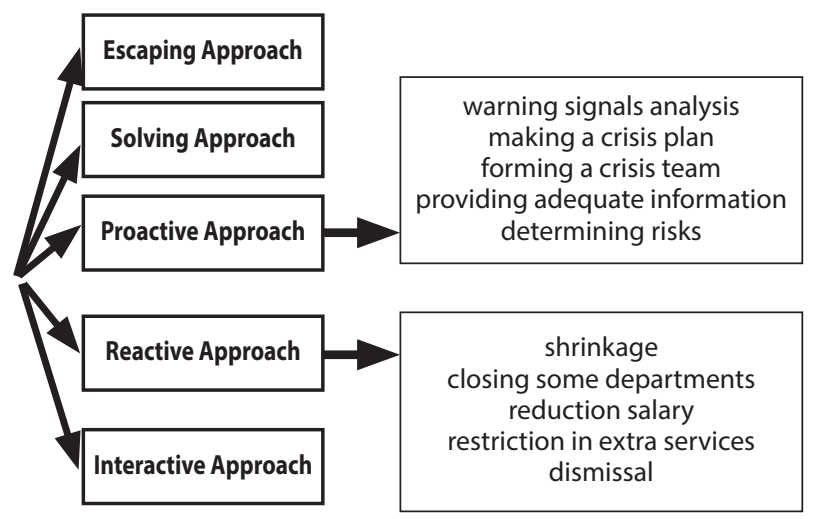

Source: Modified according to Sahin et al. (2015).

According to the authors, the escaping approach is very close to a proactive approach where management seeks to predict a possible crisis early and to find solutions or procedures that could allow the organisation to avoid a subsequent crisis. The aim is to resolve the crisis as quickly as possible. The solution approach is also aimed at the early prediction of the potential crisis as well as setting clear procedures in the crisis. Part 
of this approach is a consistent analysis of the organisational environment, which does not neglect the analysis of the strengths and weaknesses of the organisation. Attention is paid to the detailed analysis of the crisis and to ensuring the stability of all the functions of the company. In this approach, the crisis is seen as an opportunity that brings positive changes to all the activities of the organisation. The proactive approach is characterised in this model as procedures that provide timely and adequate information on the potential crisis and potential risks; creates an early warning system; crisis plans, and scenarios are drawn up; a crisis team is formed. A reactive approach is seen here as an approach that should be taken if an unexpected crisis hits the organisation. Short-term measures are taken here in the form of production cuts, reductions in the number of employees, reductive measures in financial evaluation, loss of benefits and unpaid leave. The author considers this approach to be risky for activities directed towards the employees of the organisation as well as influencing the end customers. The last approach, the interaction approach, is rather considered here as an evaluation approach of the previous steps. We can refer to organisation learning and responding to the feedback that is gained from the crisis. Communication with the stakeholders of the organisation plays an important role here. For this approach, the classic methods ${ }^{1}$ of business analysis are already known, which help to better analyse the business environment, both internal and external.

All these approaches involve proactive management elements but only an interactive approach focuses on organisational learning and highlights the importance of feedback. It is worth pointing out that the crisis is perceived as an opportunity that brings several positive changes in the organisation in the solution approach. The activities described in these approaches are also mentioned by the following authors, who describe the different phases of the reactive and proactive approach.

Mitroff, Pauchant and Shrivastava (1988) have developed a basic process model of crisis management that describes the phases that significantly affect effective crisis management. The beginning of the process of this model is in the activity of "detecting" or detecting a possible potential crisis. There is an important analysis of both the internal and external environment in which the signals of an impending crisis should be analysed. All steps are directed to a preventive function, which is to ensure the preparedness of the company for the undetected crisis. It is clear from the scheme that no organisation can prevent a possible crisis despite considerable planning and preventive procedures. Detection and prevention must be considered primarily as a process of continual evaluation of crisis plans, as these activities can better teach the organisation how to deal with the adverse situation in the most effective way. "Remediation" activities are aimed at testing and implementing the mechanisms that organisations have set up to recover an organisation after a crisis in the short and long term. The aim is to restore the business to its normal state or at least to get closer to it. The "evaluation" step is considered to be an important part of the process, as the organisation has the task of evaluating the crisis management process and revitalising the individual steps and updating the defence mechanism based on learning. The authors also deal with the idea that the more crises a company has, the better it will be prepared for further crises and will be able to respond quickly and appropriately to them.

1 The authors mention in particular SWOT analysis and PESTEL analysis. 


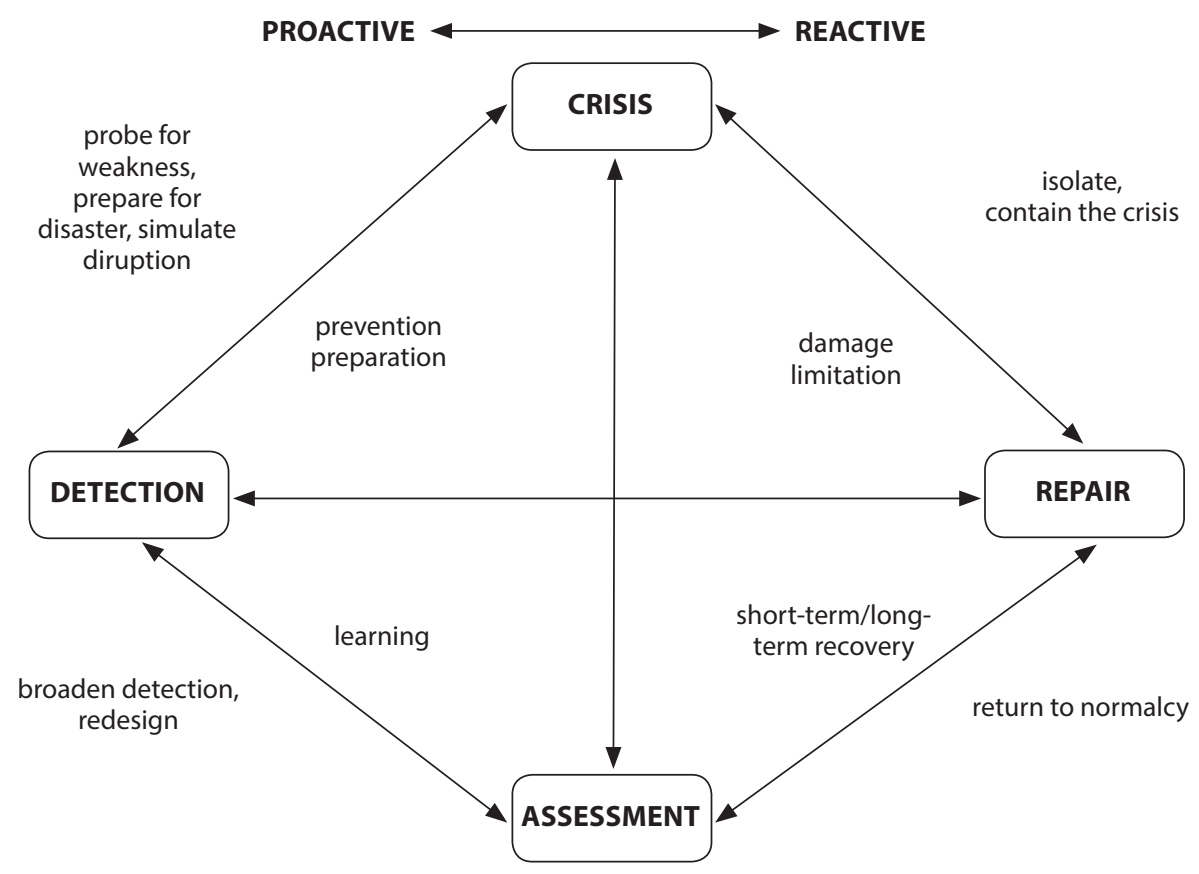

Source: Modified according to Mitroff, Pauchant and Shrivastava (1988).

Again, the necessity for proactive action in crisis management is emphasised. The reactive approach focuses on the identification and elimination of the crisis. However, it is also worth noting that the crisis cannot be averted despite planning and timely prediction in some cases. However, a thorough analysis of the environment, prediction and creation of crisis management procedures should allow the company to recover from the crisis in the shortest possible time with minimum losses. The authors cope with a conviction where the more crises strike the organisation, the more it is ready to solve further potential crises. Therefore, it is undoubtedly necessary to consider the stage of learning from the previous management procedure in the area of proactive management.

Further differences between the reactive and proactive approaches in the different phases of the crisis that may occur in an organisation were described by Spillan (2000). In the reactive approach, all activities again focus on addressing and eliminating the consequences of the crisis. The view of proactive management leads to the prevention of the crisis, and in some cases, to total avoidance. The reactive approach does not consider any warning signals and there is a crisis to which it reacts and creates crisis plans. To restore the company to balance, it is often necessary to introduce personnel measures or change the management style. In some cases, the organisation goes into bankruptcy. On the other hand, the proactive style of crisis management seeks to identify the manner of a potential crisis on time, which can be revealed through a thorough analysis of the organisation's vulnerability and early warning signals. Emergency plans or scenarios are developed 
to enable the organisation to avoid a crisis based on these studies. However, this process is not completed - after the crisis, the crisis plans are reviewed, the vulnerability is analysed again, and further prevention planning is planned.

This model mentions the possibility of crisis averting due to consistent planning and creation of crisis scenarios, which are based on the analysis of warning signals. Like previous authors (Mitroff, Pauchant and Shrivastava, 1988; Sahin et al. 2005), the author also mentions the significance of feedback that translates into new vulnerability analysis and consequently into a crisis scenario.

\section{Figure 6 | Issues and crisis management relational model}
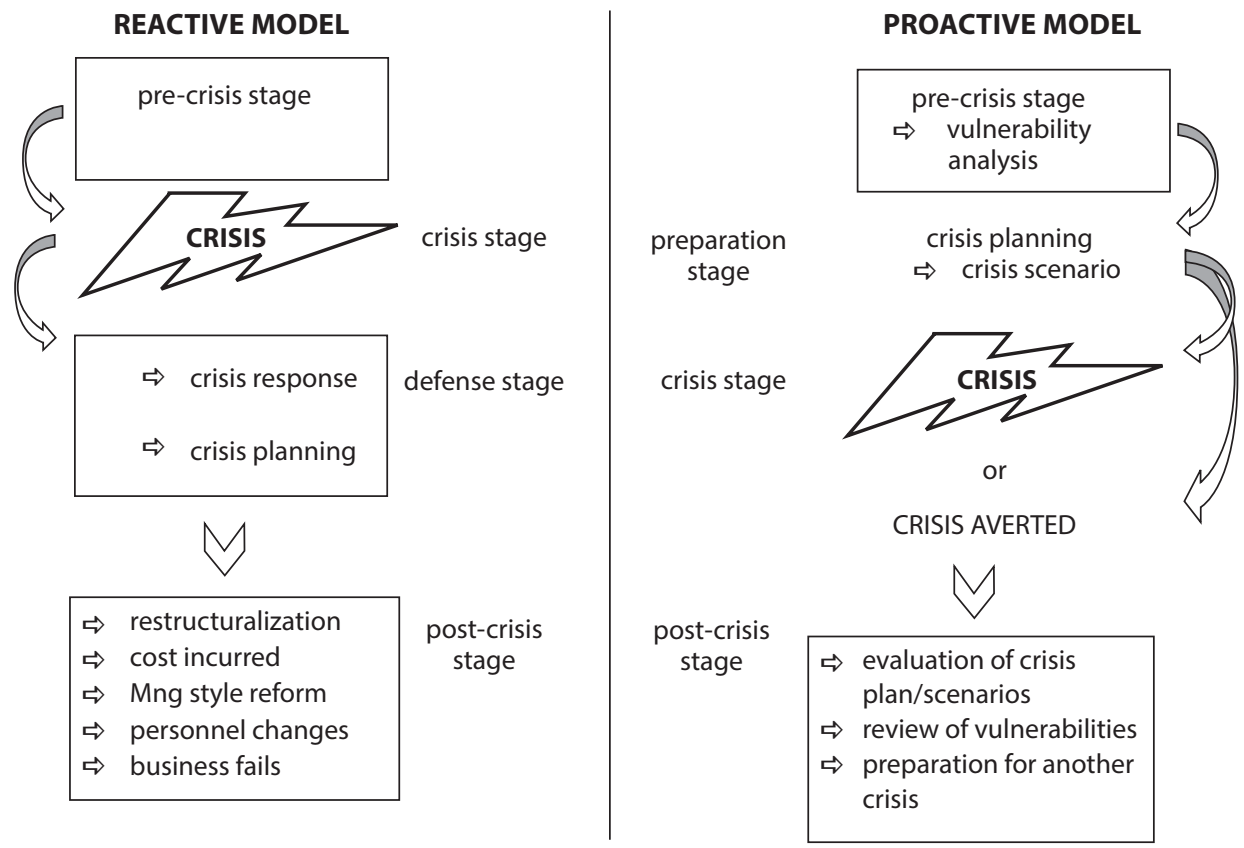

Source: Modified according to Spillan (2000).

Very similar characteristics are presented in the issues and crisis management relational model developed by Jaques (2010). The author highlights the crisis preparedness and pre-crisis prevention phases. These phases help the organisation to better prepare and respond adequately to a potential crisis. Both the mentioned approaches include planning of an entire crisis management process, creating manuals and procedures to help deal with the crisis; training of employees using simulations; identifying warning signals leading to a potential crisis; risk management and preparation of emergency actions and plans. The author does not directly call these phases of proactive management, but precrisis management, which leads to effective crisis management. However, considering all the activities described, these steps indicate elements of a proactive management style. Crisis management is then understood as reactive management, where it is necessary to consistently analyse the situation of the company after the crisis. 
Figure 7 | Crisis management process - different model

Crisis Management

Pre-crisis Management

\begin{tabular}{|c|c|c|c|c|c|}
\hline & & $\begin{array}{l}\text { Evaluation, } \\
\text { Modification }\end{array}$ & $\begin{array}{l}\text { Planning } \\
\text { Process }\end{array}$ & & \\
\hline & $\begin{array}{c}\text { Post-crisis } \\
\text { Issue Impact }\end{array}$ & $\begin{array}{c}\text { post-crisis } \\
\text { Mgmt }\end{array}$ & $\begin{array}{c}\text { crisis } \\
\text { preparedness }\end{array}$ & $\begin{array}{l}\text { Systems, } \\
\text { Manuals }\end{array}$ & \\
\hline $\begin{array}{c}\text { Recovery, } \\
\text { Business } \\
\text { Resumption }\end{array}$ & $\begin{array}{c}\text { post-crisis } \\
\text { Mgmt }\end{array}$ & \multirow{2}{*}{\multicolumn{2}{|c|}{$\begin{array}{c}\text { EFFECTIVE } \\
\text { CRISIS } \\
\text { MANAGEMENT }\end{array}$}} & $\begin{array}{c}\text { crisis } \\
\text { preparedness }\end{array}$ & $\begin{array}{l}\text { Trainning, } \\
\text { Simulations }\end{array}$ \\
\hline \multirow[t]{3}{*}{$\begin{array}{c}\text { Crisis } \\
\text { Management }\end{array}$} & $\begin{array}{c}\text { crisis event } \\
\text { Mgmt }\end{array}$ & & & $\begin{array}{c}\text { crisis } \\
\text { prevention }\end{array}$ & $\begin{array}{c}\text { Early } \\
\text { Warning }\end{array}$ \\
\hline & $\begin{array}{l}\text { System } \\
\text { Activation/ } \\
\text { Response }\end{array}$ & $\begin{array}{c}\text { crisis event } \\
\text { Mgmt }\end{array}$ & $\begin{array}{c}\text { crisis } \\
\text { prevention }\end{array}$ & $\begin{array}{l}\text { Issue and } \\
\text { Risk } \\
\text { Management }\end{array}$ & \\
\hline & & $\begin{array}{c}\text { Crisis } \\
\text { Recognition }\end{array}$ & $\begin{array}{l}\text { Emergency } \\
\text { Response }\end{array}$ & & \\
\hline
\end{tabular}

Source: Modified according to Jaques (2010).

The scientific literature also discusses algorithms that capture the activities of these two approaches without clearly indicating them. Frýbert (1995) captures the position of crisis management at certain stages of the crisis and provides a generalised approach on how to get the business out of the crisis. All steps are divided into individual phases. The first phase deals with preliminary analysis and identification of a possible potential crisis. If a company is hit by a crisis, the subsequent identification of the crisis and its sources will follow. There are authorities in place to deal with and seek to stabilise the crisis. In this case, we are already talking about crisis management, which in its current state seeks to restore the basic functions of the company. This is followed by a diagnostic phase that determines the impact of the crisis on the company. At this stage, the decisionmaking area leading to accession to the revitalisation of the business end eventually to the termination of the company and subsequent liquidation arises. In the case of a positive decision, the concept of revitalisation is established and follow-up measures are taken. These measures are subject to detailed analysis and lead to further strategic planning decisions. In this area, it is necessary to assess the current set-up of the strategy and take appropriate measures to update it if necessary.

The algorithm is not obvious at first glance as it is a description of the reactive or the proactive approach. However, proactive elements of crisis management can be derived from the model's characteristic. Clearly, these are activities in the area of crisis prediction. The author also mentions the connection to the concept of strategy. The strategy under this crisis management process should be modified based on the findings and feedback. Its revitalisation helps to successfully implement the strategy and overcome obstacles in terms of potential threats. 
Figure 8 | Algorithm for crisis solution by Frýbert

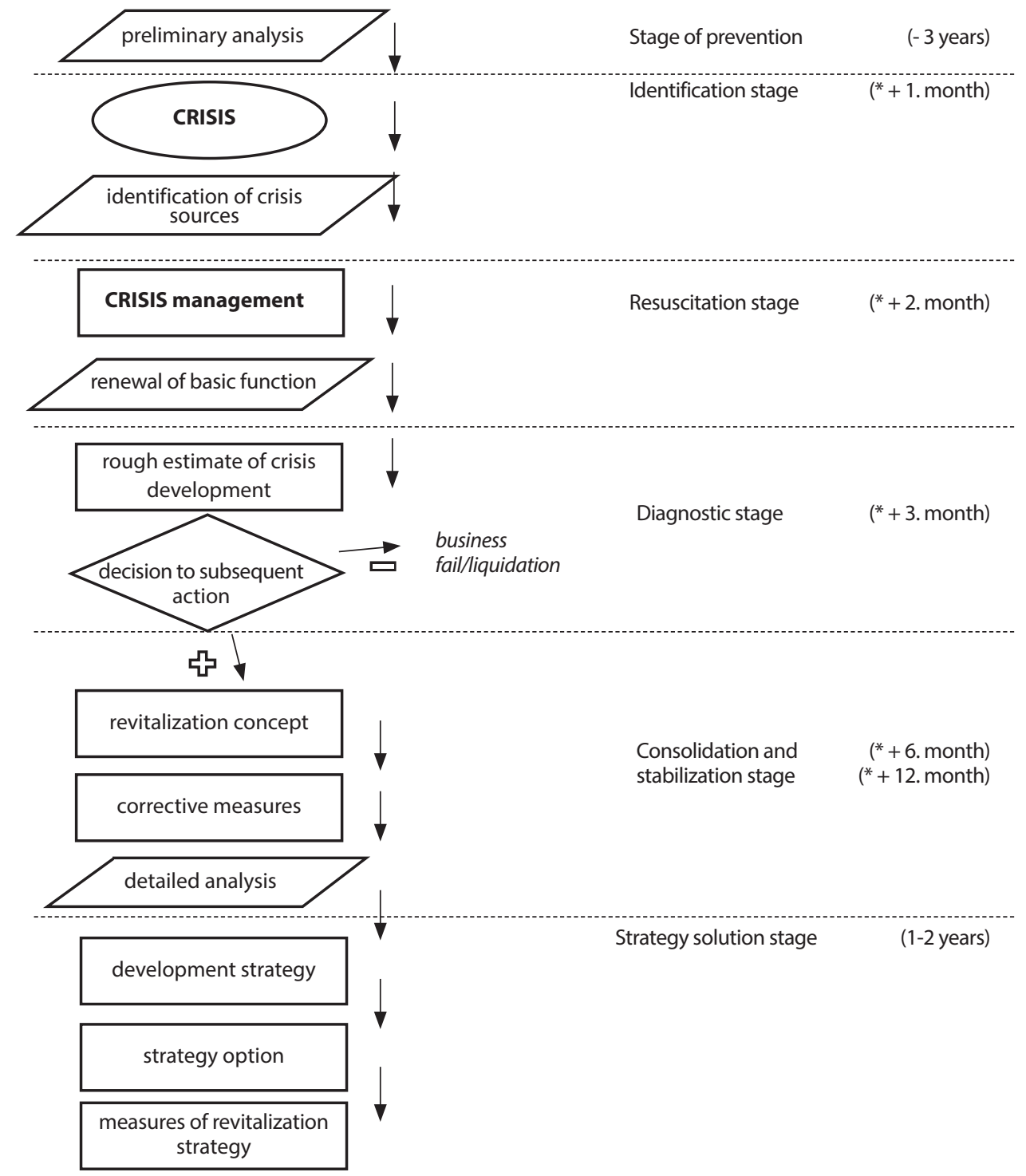

Source: Modified according to Frýbert (1995).

The last model that is described is the model designed by Valackiene (2011). The model describes other significant parts of crisis management such as the socialisation of employees in the organisation, effective communication between them, effective crisis communication and effective crisis management strategies in the organisation. This model emphasises the role of crisis communication and the need to identify the organisation's employees with their role in the organisation. In crisis communication, the emphasis is placed on setting a communication strategy with both internal and external 
customers. Of course, the internal customer is the employee and the external customer is the stakeholder. An important point is having an effective crisis management strategy, which the author divides into several phases: the creation of a crisis prevention programme, identification of a crisis, operational activities and liquidation of the consequences of the crisis. This procedure is considered to be a repetitive cycle.

Again, we see the aspects of a proactive management style and the necessity for a repeated cycle that delivers important information for decision-making in other vital areas of corporate management such as personnel management and communication within the organisation. Adoption of proposed pre-crisis measures in times of crisis needs to be communicated across the organisation. It is important to include company employees in the crisis management process as it is essential to maintain their role and belonging to the organisation. The author does not neglect the stakeholders of the organisation and the importance of communication between them in times of crisis. This model does not directly consider the procedures leading to organisation preparedness and discuss any crisis management mechanism.

\section{Figure 9 | Theoretical matrix of a crisis management model}

ESI - Employee social identification in organization
ECE - The effective communication between employees
ECC - The effective crisis communication
EXMS - The effective crisis management strategy in organization

Source: Modified according to Valackiene (2011).

\section{Discussion and Findings}

The purpose of this paper was the literature review, the summarisation of previous approaches and finding the common features. To summarise, crisis management can be perceived as a proactive process with the given steps and features, with the aim of preventing and effective dealing with a crisis. In some cases, this process can be ended by the liquidation of the company but rather seeks to restore its functions, so the whole process is repeated. Thus, the crisis management process can be considered cyclical if the organisation is not liquidated due to the consequences of the crisis. These steps in this process are illustrated below in Figure 7 - Proactive Crisis Management Process (PCMP). This model characterises individual proactive crisis management procedures that have been identified and modified based on literature research. Important aspects of a proactive crisis management approach are summarised as follows: 
- a set of methods, approaches and tools used to prevent and, if necessary, eliminate a crisis situation and stabilise organizational functions,

- the purpose is to avoid a potential crisis, minimise the extent of the losses that have arisen from the crisis and reduced the crisis duration,

- the permanent evaluation of warning signals is an essential part,

- proactive crisis management is a continuous process of prediction, prevention and preparedness, control, recovery, learning and evaluation of the whole process,

- remember that no crisis management approach will not avert all crises, sometimes only eliminate the consequences of crisis damage, mitigate the crisis and effectively deal with it.

The types of crisis, which were also defined by several authors, are mentioned in the analysed paper (Robert and Lajtha, 2002; Granville, 2002; Zuzák, 2009; Mikušová and Horváthová, 2019). These types of crises were incorporated into this model because we can identify it in the pre-crisis stage, which serve as an early warning signal.

The first step, a part of proactive management, is the prediction of the crisis in the form of vulnerability analysis in the organisation, which can be referred to as the pre-crisis phase. This consistent analysis leads to the identification of warning signals, which serve as a basis for crisis plans and scenarios. In the pre-crisis period, the organisation is facing a potential and latent crisis. The potential crisis is known as a crisis that can occur in the organisation and become evident in the form of warning signals. This crisis converts to a latent crisis bringing more threats. If the organisation takes timely corrective action, the consequences of the crisis will be not significant for the organisations. In the event of the crisis as supportive tools for preventive measures, crisis plans and scenarios, then a simulation of certain situations and training of employees can be used. To resolve the crisis, a crisis team or crisis manager should be established to deal with it. The role of the team and the managers is not only determined in the event of a crisis but should also be activated to a certain degree in the pre-crisis period, at least in terms of knowledge of the preventive measures or the mechanisms that are implemented.

The aim of proactive management is to avoid the crisis or mitigate its consequences. However, as mentioned in the description of the concept of Mittrof, Pauchant and Shrivastava (1988), it cannot be assumed that this will happen. If, after all, the organisation goes into crisis, then it can be referred to as the defensive and recovery phase, where the main activity is aimed at a consistent identification of the crisis and its causes. We are now already referring to the third type of crisis, the acute crisis, which threatens the organisation and its stability, and it is necessary or almost inevitable to approach with measures to recover the organization's plans. Restructuring (Shönfeld et al., 2018), redesign or reengineering (Champy and Hammer, 1993; Luca, 2014; Repa, 2009) can be used as a solution and corrective action, when it is necessary to reassess the overall or particular activities of an organisation, especially its processes. In some cases, as a result of the crisis, the company will be rescued (Synek, 2011; Schönfeld et al., 2018), which allows the organisation to stabilise its operations although the restructuring rate is greater. In these cases, the managers and the crisis teams focus on personnel reform, reengineering the organisation's activities, reforming the organisation's management style and then modifying the strategy to update the steps that lead to its implementation. 
The last phase of this approach is the post-crisis phase, where the main aim of this model is to avoid a potential crisis. Due to a thorough analysis of the vulnerability of the organisation, early warning signals were identified, and the further potential crisis situation is evaluated at this stage. Based on the experience gained, the warning signals should be reviewed again and the steps leading to avoiding the crisis. At this point, it is necessary for the crisis managers or crisis teams to look at the key indicators that enable averting the crisis. Crisis communication between crisis teams, managers and the organisation's management plays an important role. Given the need to revitalise the business strategy and strategic planning, this communication is crucial.

This model also mentions the essential organisations learning providing feedback in terms of evaluating the overall crisis management procedure and mechanisms. Again, crisis communication plays an important role, both with employees and the external environment - stakeholders and customers. A top management opinion should be issued on the overall assessment of crisis management, which should be communicated across the organisation. The last step in the process is the area of strategic management. As mentioned in the literature research, crisis management should play an essential role in strategic planning. If we talk about the revitalisation of strategy, based on the experience gained during crisis management, it is necessary to link the crisis plans or scenarios with strategic plans. A key role will be played by the analysis of warning signals in the form of indicators significantly affecting the operation of the entire organisation and the redesign of crisis management procedures. At this stage, we can again encounter a potential crisis, because this process is continuous, and the organisation's vulnerability is being analysed again.

Figure 10 | Proactive crisis management process (PCMP)

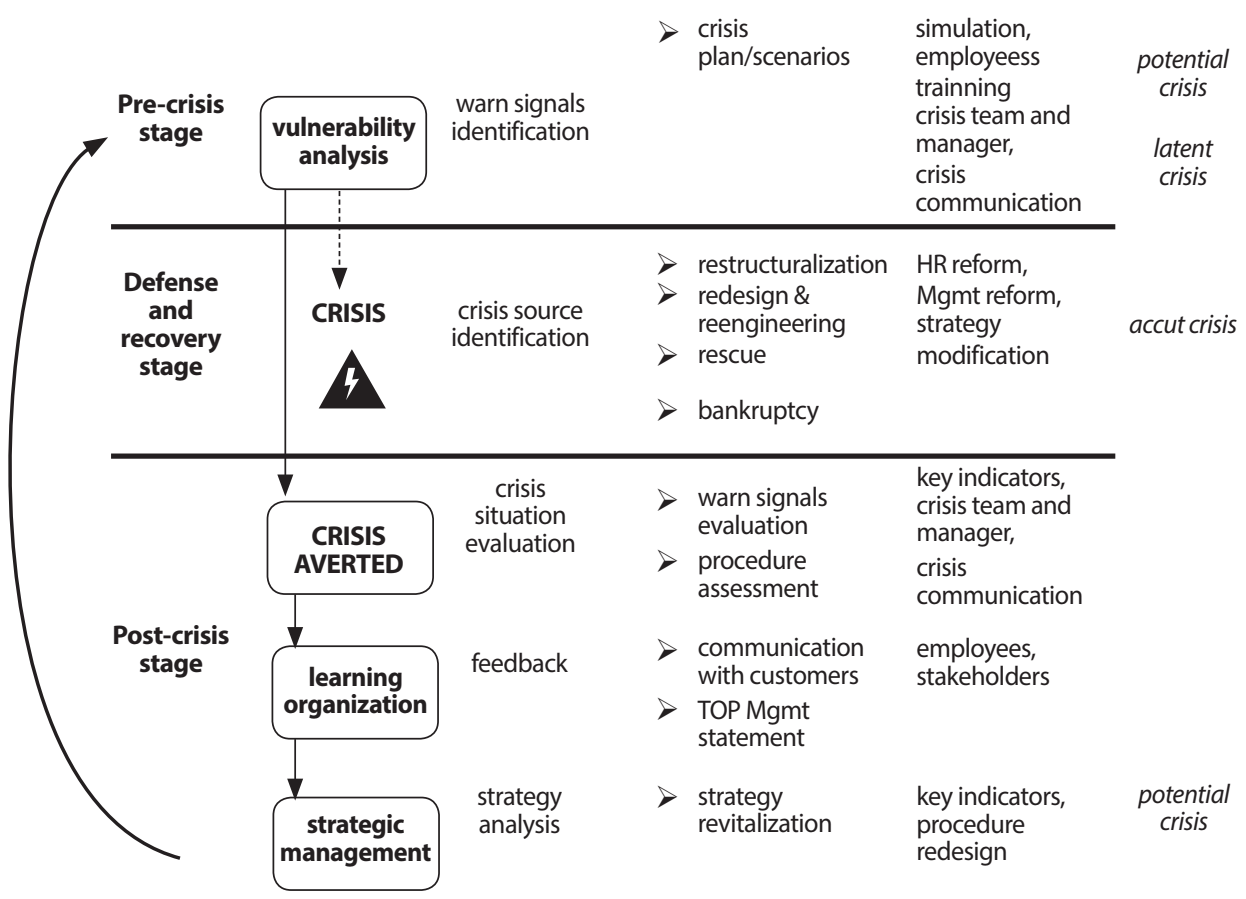

Source: Author's own processing 
This paper reviewed 98 literature sources where 38 literature sources, particularly journal papers, targeting the scope of crisis management approaches were synthesised. The paper has several contributions in the field of crisis management approaches. First, it provides an analysis of previous crisis management approaches bringing a comprehensive view of this issue. Second, it proposes the Proactive Crisis Management Process model that can be summarised as follows: consistent analysis of the organisation's vulnerability with the identification of warning signals and implementation of crisis management mechanism; if successful, the crisis can be averted and the potential crisis situation be assessed; use feedback in organisational learning, which will bring an overall assessment of crisis management procedures; deal with strategic management in the sense of integrating crisis management into strategic planning and strategy revitalisation.

Many of the specific features of the model presented here previously have not been operationalised. Therefore, the opportunities for further research in the area of proactive crisis management process are obvious. In view of the fact that a significant part of proactive crisis management is the identification of warning signals and the creation of a crisis mechanism, it is necessary to develop a clear procedure for this step at the pre-crisis stage. It is evident that a research gap in the domain of empirical research where a researcher can verify the mentioned features of this model and can explore the crisis management process steps is required. The proposed model depicts some features that are not particularly well-described and are mainly characterised on a theoretical or descriptive level. This insufficiency can be seen in the field of warning signal identification and in the establishment and evaluation of the key indicators of crisis mechanism. Future research should be aimed at the organisation's crisis management, where researchers benchmark proactive crisis management process in the organisation and analyse the process of warning signal detection in more detail. General research questions could be the following: What proactive procedures of the crisis management process are effective for identifying a potential crisis? Is it necessary to include all the mentioned model features for effective crisis management? Do proactive approaches bring positive results in the stage of potential crisis identification? What is an effective way of identifying the warning signals in the organisation? Is it possible to identify the key indicators in the organisation that carry information about possible crisis?

To conclude, given the analysed literature, the proactive crisis management process should be able to detect the potential crisis and ensure the preparedness of the organisation to future threats. For this reason, it is necessary to conduct empirical research and to enrich the conceptual model with crisis management for organisations.

\section{References}

Antušák, E. (2009). Krizový management. Hrozby, krize, přiležitosti [Crisis Management: Threats, Crises, Opportunities]. Praha: Wolters Kluwer.

Antušák, E. (2013). Krizová připravenost firmy [Organizational Crisis Preparadness]. Praha: Wolters Kluwer.

Augustine, N.R. (1995). Managing the Crisis You Tried to Prevent. Harvard Business Review, 73(6), pp.147-158.

Coombs, W.T. (2007). Crisis Management and Communications. Institute of Public Relations.

Crandall, W.R., Parnell, J.A., and Spillan, J.E. (2013). Crisis Management: Leading in the New Strategy Landscape. Thousand Oaks, CA: SAGE Publishing.

Fink, S. (1986). Crisis Management: Planning for the Inevitable. Lincoln, NE: iUniverse. 
Frýbert, B. et al. (1995). Jak transformovat podnik [How to Transform an Enterprise]. Ostrava: Montanex.

Hammer, M., and Champy, J. (1993). Reengineering the Corporation: A Manifesto for Business Revolution. New York, NY: HarperBusiness.

Jaques, T. (2010). Reshaping Crisis Management: The Challenge for Organizational Design. Organizational Development Journal, 28(1), pp. 9-17.

King, G. (2002). Crisis Management \& Team Effectiveness: A Closer Examination. Journal of Business Ethics, 41(3), pp. 235-249. https://doi.org/10.1023/A:1021200514323

Khodarahmi, E. (2009). Crisis Management. Disaster Prevention and Management: An International Journal, 18(5), pp. 523-528. https://doi.org/10.1108/09653560911003714

Knopf, J.W. (2006). Doing a Literature Review. Political Science and Politics, 39, pp. 127-132.

Kouzmin, A. (2008). Crisis Management in Crisis? Administrative Theory \& Praxis, 30(2), pp. 155-183. https://doi.org/10.1080/10841806.2008.11029631

Loosemore, M., and Hughes, W. (1998). Reactive Crisis Management in Construction Projects - Patterns of Communication and Behaviour. Journal of Contingencies and Crisis Management, 6(1), pp. 23-34. https://doi.org/10.1111/1468-5973.00065

Luca, M. (2014). Business Process Reengineering. Risk in Contemporary Economy, 1, pp. 233-236.

Mikušová, M. (2014). Krizový management pro malé a střední podniky [Crisis Management for Small and Medium Enterprises]. Bratislava: Wolters Kluwer.

Mikušová, M., and Horváthová, P. (2019). Prepared for a Crisis? Basic Elements of Crisis Management in an Organisation. Economic Research-Ekonomska Istraživanja, 32(1), pp. 1844-1868. https://doi.org/10.1080/1331677X.2019.1640625

Mitroff, I.I., and Alpaslan, M.C. (2003). Preparing for Evil. Harvard Business Review, 81(4), pp. 109-115.

Mitroff, I.I., Pauchant, C., and Shrivastava, P. (1988). The Structure of Man-made Organizational Crises Conceptual and Empirical Issues in the Development of a General Theory of Crisis Management. Technological Forecasting and Social Change, 33(2), pp. 83-107. https://doi.org/10.1016/0040-1625(88)90075-3

Mitroff, I. I., Pearson, C. M. (1993). Crisis Management: A Diagnostic Guide for Improving Your Organization`s Crisis-Preparedness. San Francisco: Jossey-Bass.

Moher, D., Liberati, A., Tetzlaff, J., and Altman, D.G. (2009). Preferred Reporting Items for Systematic Reviews and Meta-analyses: The PRISMA statement. British Medical Journal (BMJ), 6(7), pp. 1-6. https://doi.org/10.1371/journal.pmed.1000097

Paraskevas, A. (2006). Crisis Management or Crisis Response System? A Complexity Science Approach to Organizational Crises. Management Decision, 44(7), pp. 892-907. https://doi.org/10.1108/00251740610680587

Pearson, C.M., and Mitroff, I.I. (1993). From Crisis Prone to Crisis Prepared: A Framework for Crisis Management. The Executive 7(1), pp. 48-59. https://doi.org/10.5465/ame.1993.9409142058

Pearson, C.M., and Clair, J.A. (1998). Reframing Crisis Management. The Academy of Management Review 23(1), pp. 59-76. https://doi.org/10.2307/259099

Pollard, D., and Hotho, S. (2006). Crises, Scenarios and the Strategic Management Process. Management Decision, 44(6), pp. 721-736. https://doi.org/10.1108/00251740610673297

Preble, J.F. (1997). Integrating the Crisis Management Perspective into the Strategic Management Process. Journal of Management Studies, 34(5), pp. 769-791. https://doi.org/10.1111/1467-6486.00071 
Rais, R. (2007). Specifika krizového managementu [Crisis Management Specification]. Brno: KEY Publishing.

Regester, M. (1989). Crisis Management. What to Do when the Unthinkable Happens. London: Century Hutchinson.

Řepa, V. (2012). Procesně řízená organizace [Process Driven Organization]. Praha: Grada.

Robert, B., and Lajtha, C. (2002). A New Approach to Crisis Management. Journal of Contingencies and Crisis Management, 10(4), pp. 181-191. https://doi.org/10.1111/1468-5973.00195

Sahin, S., Ulubeyli, S., and Kazaza, A. (2015). Innovative Crisis Management in Construction: Approaches and the Process. Procedia - Social and Behavioral Sciences, 195, pp. 2298-2305. https://doi.org/10.1016/j.sbspro.2015.06.181

Saunders, M., Lewis, P., and Thornhill, A. (2012). Research Methods for Business Students (6th edition). London: Prentice Hall.

Shrivastava, P., and Mitroff, I. (1987). Strategic Management of Corporate Crisis. The Columbia Journal of World Business, 22(1), pp. 5-11.

Shrivastava, P., Mitroff, I.I., Miller, D. and Miglani, A. (1988). Understanding Industrial Crises. Journal of Management Studies, 25(4), pp. 285-303. https://doi.org/10.1111/j.1467-6486.1988.tb00038.x

Schoemaker, P.J.H. (1993). Multiple Scenario Development: Its Conceptual and Behavioral Foundation. Strategic Management Journal, 14(3), pp. 193-213. https://doi.org/10.1002/smj.4250140304

Schönfeld, J. et al. (2018). Transformace a restrukturalizace podniku [Business Transformation and Restructuring]. Praha: C.H. Beck.

Spillan, J.E. (2000). Strategies for Successful Crisis Management [online]. Available at: http://webapps.roanoke.edu/businessweb/SEINFORMS\%202008\%20-\%20Proceedings/ proc/p080429001.pdf [Accessed 24 Jun. 2019]

Synek, M. (2011). Manažerská ekonomika (5. vydání) [Managerial Economics (5th ed.)]. Praha: Grada.

Valackiene, A. (2011). Theoretical Substation of the Model for Crisis Management in Organization. Inzinerine Ekonomika-Engineering Economics, 22(1), pp. 78-90. https://doi.org/10.5755/j01.ee.22.1.221

Wagner, C.G. (2005). Proactive Crisis Management. The Futurist 39(2), p. 6.

Zapletalová, Š. et al. (2012). Krizový management podniku pro 21. století [Crisis Management for the 21st Century]. Praha: Ekopress.

Zuzák, R., and Königová, M. (2009). Krizové rízení podniku [Business Crisis Management]. Praha: Grada.

Zuzák, R. (2009). Z podnikových krizí k vítězství (kdy krize je príležitostí) [From Corporate Crises to Victory (When Crisis Is an Opportunity)]. Praha: Alfa Publishing. 